\title{
Board Characteristics and Firm Performance: Evidence from Malaysian Public Listed Firms
}

\author{
Satirenjit Kaur Johl, Shireenjit Kaur, and Barry J. Cooper
}

\begin{abstract}
The aim of this study is to examine the impact of board characteristics and firm performance. Specifically we test the effects of board meeting, board independence, board size and directors accounting expertise on firm accounting performance. The paper uses both financial and non-financial data from annual reports of the $\mathbf{7 0 0}$ public listed firms in Malaysia for the year 2009. The result shows that board independence does not affect firm performance, whilst board size and board accounting/financial expertise are positively associated with firm performance. Board diligence in terms of board meetings is found to have an adverse effect on firm performance. These findings provide some implication for future research on the effectiveness of board directors on firm performance.
\end{abstract}

Index Terms-Corporate governance, board characteristics, board meeting, board independence, accounting expertise and firm performance.

\section{INTRODUCTION}

In recent years considerable attention has been given in the economic and finance literature on the impact of corporate governance on firm performance. This increased attention has been motivated by the $1997 / 1998$ Asian financial crisis that badly affected most of the Asian countries which has changed the landscape of the countries corporate governance including Malaysia. In Malaysia, efforts to improve corporate governance practices began in 1993 when the audit committee was made mandatory for the Kuala Lumpur Stock Exchange (KLSE) listing requirements due to major corporate fraud that occurred in Bank Bumiputra, Perwaja Steel and Bank Islam [1] and [2]. The most important initiatives taken toward increasing quality of corporate governance were the implementation of Malaysian Code of Corporate Governance (MCCG) in March 2000, and the setup of Minority Shareholders Watchdog Group (MSWG) in 2001 [3]. In 2007 and 2012 revisions were made to the MCCG which were aimed at strengthening the roles and responsibilities of the board of directors and audit committee. A majority of the members need to comprise of independent non-executive directors who are financially literate [4]. Other efforts undertaken by the government were the amendments to the Companies Act 1965, the Securities Industry Act 1983, the Securities Commission Act 1993, the Banking and

Manuscript received September 1, 2013; revised November 11, 2013.

S. K. Johl is with the Universiti Teknologi PETRONAS, Management \& Humanities Department, Bandar Sri Iskandar, 31750, Perak, West Malaysia (e-mail: satier@petronas.com.my).

S. Kaur and B. J. Cooperis are with the University Deakin, School of Accounting, Economics and Finance, Melbourne, Australia (e-mail: shireenjit.johl@deakin.edu.au, barry.cooper@deakin.edu.au).
Financial Institutions Act 1989 and the Bursa Malaysia Securities Listing Rules to promote greater transparency and integrity among public listed firms.

The primary purpose of this study is to provide empirical evidence concerning board characteristics and firm performance. Board of directors is seen as the most important corporate governance mechanism that monitors and advises the top management in performing their responsibility to protect the shareholders' interest [5] and [6]. Therefore by investigating board characteristics such as board independence, board meeting, board size and accounting expertise of directors, this study hopes to bring new approaches for researchers and regulators on the importance of board director's characteristics and firm performance. In addition, prior research has shown that one stream of researchers found that board characteristics were able to provide positive impact on firm performance whereas another stream of researchers found that there is no relationship between board characteristics and firm performance To reconcile the inconsistencies and inconclusive findings from previous studies this study investigated the relationship between board characteristics and firm performance for the 700 public listed Malaysian companies.

\section{LITERATURE REVIEW}

\section{A. Board Independence}

The board comprises of executives and non-executives who are either independent or non-independent directors. The non-executive directors (NEDs) need to play a role in monitoring the actions of the CEO and executive directors to ensure that the shareholders' interests are well cared for and to add to the diversity of skills and expertise of the directors [7] and [8]. The Malaysian Code on Corporate Governance (2000) and the revised code 2007 recommend that it is the best practice to have a balance membership board of directors where independent NEDs should make up at least one third of the board membership. This is to ensure the effectiveness of the independent directors in maintaining good decision making for the company. In Pakistan, Awan [9] discovered a positive relationship between NEDs and firm performance measured using return on asset (ROA) and return on equity (ROE). Another study that was conducted among Belgian companies found a significant relationship between the number of outside directors and ROE which supports the notion that outsiders are able to perform a monitoring function as a result of their independence and the interest of the shareholders are well protected [10].

Despite the advantages of having more NEDs on the board, 
prior studies have shown contrary result from the analyses of the relationship between the NEDs and firm performance. According to Weir \& Liang [7] non-executive directors are only employed on a part-time basis and are therefore likely to have other work commitments, they may lack the expertise necessary for understanding highly technical business issues and may have insufficient information when required to make key decisions. A study conducted by Abdullah [8] in Malaysia used data from the (KLSE) Main Board for the period between 1994 and 1996 found that there is no significant difference in performance between firms with independent boards and firm with non-independent boards. Similar findings were reported by Haniffa \& Hudaib [2] and Rahman \& Mohamed Ali [11] that non-executive directors had no influence on firm performance. This could be due to in many developing countries including Malaysia the selection of the independent directors is not based on their expertise and experience but more for political reasons to legitimate business activities and contracts [2]. In contrast, a study conducted by Salleh et al. [12] found that a higher percentage of non-executives has created better auditing systems and improved financial reporting timeliness [13]. Zainal Abidin et al. [14] found evidence that a higher proportion of independent non-executive directors on the board have a positive impact on firm performance based on value added intellectual coefficient measurement. This study addresses and investigates the conflicting issue of whether a high proportion of outsider directors have an impact on the firm performance of an organisation. Therefore, this study proposes the following hypothesis:

$\mathrm{H} 1$ : There is no relationship between the ratio of outsiders on the board and the firm performance.

\section{B. Board Meeting}

According to the requirement of the Revised 2007 Malaysian Code on corporate governance, companies are encouraged to have regular board meetings for discharging duties and responsibilities. Also, it is mandatory for the board to disclose the number of board meetings held in a year and details of the attendance of each individual director in respect to meetings held. Frequency of board meetings is considered to be an important way of improving the effectiveness of the board [15] and [16]. It is argued that board meetings and attendance of the meetings are considered to be important channels through which directors obtain firm specific information and able to fulfill their monitoring role. A study conducted by Francis et al. [17] indicated that firms with poor board attendance at meetings perform significantly worse than boards which has good attendance during financial crisis. In addition, Ntim \& Oser [18] conducted a study in South Africa which also suggested similar findings between the frequency of board meetings and corporate performance where boards that meet more frequently tend to generate higher financial performance.

On the other hand, there are researchers that consider board meetings not necessarily useful due to the limited time non-executives spend with the company and consider such time could be better utilised for a more meaningful exchange of ideas with the management [19]. Also, frequent meetings involve managerial time and increase travel expenses, administrative support requirements and directors' meeting fees. This may affect enterprise activities within the firm as resources are being channeled towards less productive activities [20]. A study conducted by Johl [21] in the U.K among the FTSE 100 companies found there was a negative relationship between frequency of board meetings and entrepreneurial activities in firms.

Drawing on the arguments from the above, there have been inconclusive findings on the frequency of board meetings with firm performance where this study seeks to address. In addition there is a heavy concentration of existing studies on developed countries such as Europe and North America which have different institutional context and corporate governance practices where the effectiveness of board meetings on firm performance can be expected to be different from the developing countries. Therefore, the following hypothesis is proposed:

$\mathrm{H} 2$ : There is a negative relationship between the frequency of board meetings and firm performance.

\section{Board Size}

Board size seems to differ from one country to another. In Malaysia, the corporate governance code does not specify the size of the board. Instead every board should examine its size, with a view to determine the impact on its numbers. There is no ideal size for a board but the right size for a board should be driven how effectively the board is able to operate as a team [22]. There have been conflicting arguments between board size and firm performance. A study conducted by Yermack [23] used Tobin's Q as an estimate of market valuation and the result shows that there is an inverse relationship between board size and firm value. Companies with small boards were found to exhibit more favorable values of financial ratios and provide stronger CEO performance incentives through compensation and the threat of dismissal. On the other hand, Dalton \& Daily [24] used the Meta analysis technique, which showed a different result in that larger boards were associated with better corporate financial performance even when considering the nature of the firm and irrespective of how financial performance was measured. Similar findings were revealed by Andres \& Vallelado [25] that larger boards were more efficient in monitoring and create more value for a firm. This finding was also supported by a study conducted by Shukeri et al. [26] who found that board size had positive influence on firm ROA. Therefore the following hypothesis is proposed:

H3: There is a positive relationship between board size and firm performance.

\section{Accounting Expertise of Directors}

The recent wave of corporate scandals in Malaysia has caused concern on the need for financial/accounting experts to be on board to ensure greater accountability on wide range of issues. According to the requirement of the Revised Malaysian Code on Corporate Governance 2007 and Corporate Governance Blueprint 2011 the boards need to ensure it has the right mix of members with appropriate skills and experience to cope with business complexities, competition and changes. However, the code did not specify on the required competencies of directors i.e. experience and 
qualifications.

Guner et al. [27] stressed it was important for board members to have an understanding of accounting principles and financial statements which will lead to better board oversight and this will serve to the better interest of shareholders. A study conducted by Wan Yusoff \& Armstrong [28] in Malaysia on board competencies and firm performance. This study conducted a qualitative approach using two stages of Delphi Technique. The findings indicated 8 competencies were found to be essential for Malaysian companies based on a personal interview with 41 participants. It was found that financial competency was the most important competency. Hambrick \& Manson [29] argued that there were two types of essential competencies necessary for the top management team of a company including company's directors: Functional knowledge and firm-specific knowledge. Functional knowledge covers knowledge in finance, accounting, legal, marketing and economics [30] and [31]. On the other hand firm-specific knowledge relates to detail information about the firm and its operation [29]. Similar results were revealed by Conger \& Ready [32] and Kor \& Sundaramuthy [33] that directors who had reasonable financial backgrounds were more effective in providing internal control system mechanisms to control firm performance.

Based on the inconsistencies in the arguments on accounting/financial expertise of board members, this study intends to further address this issue in the Malaysian context. Therefore, the following hypothesis is proposed:

H4: There is a positive relationship between accounting expertise of board members and firm performance.

\section{DATA AND RESEARCH METHOD}

Our initial sample was drawn from all Malaysian firms listed on the Bursa Malaysia by market capitalization as at 31 December 2009. The information pertaining to board characteristics were obtained from 2009 annual reports. Data relating to financial information were extracted from the OSIRIS database. Firms with insufficient director and financial data were excluded from the regression analysis. Thus, the process led to a final sample of 731 observations.

Table I presents the descriptive summary of our sample firms in terms of firm performance and board characteristics. The firm size in terms of total assets ranges from RM2.59 million to RM71.4 billion, while the mean and the standard deviation of the sample is RM1.25 and RM4.73 billion respectively. In terms of debt, the sample firms have an average debt ratio with mean of about 0.21 of total assets respectively and ranges between 0 and 0.66 of total assets. Moving to firm performance, given the global financial crisis it was not surprising that the sample firms yield low returns (but positive) as indicated by their Return on Assets and Bankruptcy Score (ROA, and ZSCORE mean of about 0.02 and 3.0 respectively).

For the board characteristics in terms of board independence, the mean of independent members on the board of directors in the sample is 44 percent and ranges between 0 and 100 percent. The average frequency of board meetings in a year is 5 times and ranges between 0 and 24 times in a year. It appears that the banking and financial sector tend to have much more regular board meetings due to the nature of the business. Turning to board size on average it has 7 members on the board and it ranges from 3 to 18 members. The average proportion of board members with accounting expertise is $25 \%$ and it ranges from $0 \%$ to $85 \%$.

TABLE I: DESCRIPTIVE SUMMARY

\begin{tabular}{|l|l|l|l|l|}
\hline Tariable & Mean & $\begin{array}{l}\text { Std } \\
\text { Dev. }\end{array}$ & Min & Max \\
\hline ROA (Return on Asset) & 0.022 & 0.094 & -0.356 & 0.3043 \\
\hline $\begin{array}{l}\text { ROALAG (Prior Year's Return } \\
\text { on Asset) }\end{array}$ & 2.466 & 9.297 & -35.550 & 24.500 \\
\hline $\begin{array}{l}\text { LNASSET(Natural Log of } \\
\text { Total Assets) }\end{array}$ & 12.547 & 1.494 & 9.192 & 17.073 \\
\hline $\begin{array}{l}\text { DEBT(Total Debt to Total } \\
\text { Assets) }\end{array}$ & 0.208 & 0.164 & 0 & 0.663 \\
\hline $\begin{array}{l}\text { RDEV(Total Research } \\
\text { Development Expenditure To } \\
\text { Total Assets) }\end{array}$ & 0.0001 & 0.004 & 0 & 0.034 \\
\hline $\begin{array}{l}\text { CAPEX(Total Capital } \\
\text { Expenditure to Total Sales) }\end{array}$ & -0.069 & 0.139 & -0.95 & 0 \\
\hline ZSCORE(bankruptcy score) & 3.010 & 3.266 & -1.590 & 23.520 \\
\hline $\begin{array}{l}\text { INDBOD(proportion of } \\
\text { Independent Directors on the } \\
\text { Board) }\end{array}$ & 0.436 & 0.129 & 0 & 1 \\
\hline $\begin{array}{l}\text { LNBODMEET(no of Board } \\
\text { Meeting) }\end{array}$ & 5.30 & 1.946 & 0 & 24 \\
\hline $\begin{array}{l}\text { LNBODSIZE(No of Board } \\
\text { Members) }\end{array}$ & 7.44 & 1.936 & 3 & 16 \\
\hline $\begin{array}{l}\text { ACCEXPERTBOD(Proportion } \\
\text { of Accounting Expert on } \\
\text { Board) }\end{array}$ & 0.258 & 0.144 & 0 & 0.857 \\
\hline
\end{tabular}

The Pearson correlations (untabulated) for variables in the model suggest that generally the performance variable (ROA) was positively correlated with the test variable - board characteristics:

(INDBOD/LNBOMEET/LNBODSIZE/ACCTEXPERTB OD), total assets (LNASSETS), capital expenditure (CAPEX) and lag performance (ROALAG). The correlation sign for the rest of the variables (DEBT, RDEV and BODIND) was negative. None of the variables had correlations greater than 0.70 . In addition, to test for multicollinearity, the VIF was calculated for each independent variable and by each estimation. Prior literature suggests that a VIF value of 10 and above is a cause for concern [34]. The results (not shown in paper) indicate that all the independent variables had VIF values of less than 2 .

\section{Model SPECIFICATION AND REGRESSION RESUlts}

The relationship between board characteristics and firm performance has been tested using the following model:

PERFORM $=\alpha+\beta 1$ BODCHAR (INDBOD $/$ LNBODMEET / LNBODSIZE / ACCTEXPERTBOD) + $\beta 2$ ASSET + $\beta 3$ DEBT $+\beta 4$ CAPEXP $+\beta 5$ RDEV $+\beta 6$ LAGPERFORM + $\beta 7$ FINANCE $+\beta 8$ ZSCORE $+\varepsilon$

The description of the variables in the model (measurement and source) is listed in Table I. The dependent variable in each model is performance (PERFORM) and this is measured using Return on Assets (ROA). The accounting based performance indicators were used because capital markets in Malaysia are not as developed as in the US and 
tend to be volatile. Therefore the use of market based performance may not accurately reflect the performance of a firm.

Board characteristics are the variables used in this study. They consist of board independence, board meeting, board size and accounting expertise of board members. For each of the estimation in this study, we control for other firm characteristics which have been used in prior corporate governance and performance studies [35]. Specifically, we control for: 1) firm size measured using the natural log of assets and no direction is predicted; 2) debt ratio, which is expected to be negatively associated with performance; 3 ) firm growth opportunities, proxied by capital expenditure to total sales and research development to total sales, which is expected to be inversely related to performance; 4) prior year's performance, which is expected to be positively associated with performance; 5) bankruptcy score and 6) industry sectors.

TABLE II: REGRESSION RESULTS- BOARD CHARACTERISTICS

\begin{tabular}{|l|l|l|l|lll|}
\hline ROA & Coef. & Std.Err & $t$ & $P>t \quad[95 \%$ Conf. Interval] \\
\hline LNBODMEET & -0.0205705 & 0.010042 & $-2.05^{* *}$ & $0.041 \quad-0.040292$ & -0.0008487 \\
\hline LNBODSIZE & 0.0241152 & 0.012775 & $1.89^{* *}$ & 0.060 & -0.0009723 & 0.0492027 \\
\hline ACCTEXPERTBOD & 0.0358628 & 0.017879 & $2.01^{* *}$ & 0.045 & $0.0007521 \quad 0.0709734$ \\
\hline INDBOD & 0.0147065 & 0.025118 & -0.59 & 0.558 & -0.0640336 & 0.0346205 \\
\hline LNASSET & 0.0113408 & 0.002867 & 3.96 & 0.000 & 0.0057102 & 0.0169715 \\
\hline DEBTASSET & -0.0737162 & 0.025408 & $-2.9 * * *$ & 0.004 & -0.1236142 & -0.0238182 \\
\hline RDEV & 0.1182887 & 0.619414 & 0.19 & 0.849 & -1.098141 & 1.334719 \\
\hline CAPEX & 0.0381199 & 0.018378 & $2.07^{* *}$ & 0.038 & 0.0020283 & 0.0742115 \\
\hline LAGROA & 0.3869405 & 0.055609 & $6.96^{* * *}$ & 0.000 & 0.2777331 & 0.4961479 \\
\hline ZSCORE & 0.0023071 & 0.002059 & 1.12 & 0.263 & -0.0017372 & 0.0063514 \\
\hline
\end{tabular}

Note:* significant at $10 \%, * *$ significant at $5 \%, * * *$ significant at $1 \%$; note: industry sectors were also included, but for brevity purpose the results were not tabulated.

Table II presents the Ordinary Least Square (OLS) regression results for each of the estimations carried out. Overall, the F-stat for the model is statistically significant at 0.01 levels and the $R 2$ is around 50 percent. The results as displayed in Table II show that the coefficient for board independence (INDBOD) is negative and insignificant indicating that the involvement of independent directors on the board has no effect on firm performance. This finding is consistent with Abdullah [8], Haniffa \& Hudaib [2] and Rahman \& Mohamed Ali [11] that independent directors had no influence on firm performance. On the other hand, the coefficient of the frequency of board meeting (LNBODMEET) is negative and significant at 5\% level which indicates that the more frequent the board meetings are held it has an inverse effect on firm performance which supports H2. This finding is consistent to Johl [21], Vafeas [19], Evan et al. [20] and Lipton \& Lorsh [36] that too frequent meetings can lead to resources being channeled towards less productive activities. As for board size (LNBODSIZE) the coefficient is positive and significant at $5 \%$ level which shows larger board size has a positive effect on firm performance that supports H3. This is consistent with Daily \& Dalton [24], Andres \& Vallelado [25] and Shukeri et al. [26] where larger boards were more efficient in monitoring and creating value for firms. Similar results were indicated for accounting expertise of board members (ACCTEXPERTBOD) and firm performance. This is consistent to Conger \& Ready [32], Kor \& Sundaramuthy [33] and Ingley \& Walt [37] that board members having accounting expertise will lead to better board oversight and serve to the better interest of the shareholders.

\section{CONCLUSION}

This study determined the existence of a relationship between board characteristics and firm performance. The findings seem to suggest that greater emphasis need to be taken by firms to have larger board size, less frequent board meetings and a higher percentage of board members with accounting expertise which is argued and found in this study to have a positive implication on firm performance. However, the findings found that board independence does not affect firm performance.

In Malaysia several initiatives has been taken by the government to strengthen the board structure and composition in order to create good dynamics of board meetings discussion which will lead to better firm performance and create good value creation to shareholders. Future research could also explore on board characteristics and firm performance by using different research method. Semi structured interviews with board members will provide further insights on the effects of board characteristics and firm performance.

\section{REFERENCES}

[1] R. M. Haniffa, "Culture, corporate governance and disclosure in Malaysia Corporations," Ph.D. dissertation, Dept Business, University of Exeter, UK, 1999.

[2] R. M. Haniffa and M. Hudaib, "Corporate governance structure and performance of Malaysian listed companies," Journal of Business Finance and Accounting, vol. 33, no. 7, pp. 1034-1062, 2006.

[3] N. Subramaniam, M. M. Zain, and S. Johl, Corporate Governance Reform: The Malaysian Context, Book Chapter Nova Publishers, 2009.

[4] M. N. Ramlah and E. J. Su. (2009). Recent developments in Malaysia, International Corporate Governance Network. Yearbook. [Online]. 
Available:

http://www.sc.com.my/eng/html/resources/ICGN_Yearbook.

[5] E. F. Fama and M. C. Jensen, "Separation of ownership and control," Journal of Law and Economics, vol. 26, pp. 301-325, 1983.

[6] B. E. Hermalin and S. M. Weisbach, "Boards of directors as an endogenously determined institution: A survey of the economic literature," Federal Reserve Bank of New York Economic Policy Review, vol. 9, no. 1, pp. 7-26, 2003.

[7] L. Weir and D. Laing, "Governance structures, director independence and corporate performance in the U.K," European Business Review, vol. 13, no. 2, pp. 86-94, 2001.

[8] S. N. Abdullah, "Board composition, CEO duality and performance among Malaysian listed Companies," Corporate Governance International Journal of Business in Society, vol. 4, pp. 47-61, 2004.

[9] S. H. Awan, "Effect on board composition on firm performance: A case of Pakistan listed companies," Interdisciplinary Journal of Contemporary Research in Business, vol. 3, no. 10, 2012.

[10] A. Dehaene, V. D. Vuyst, and H. Ooghe, "Corporate performance and board structure in Belgian companies," Long Range Planning, vol. 34, no. 3, pp. 383-398, 2001

[11] R. A. Rahman and F. H. M. Ali, "Audit committee, culture and earnings management: Malaysian evidence," Managerial Auditing Journal, vol. 21, no. 7, pp. 783-804, 2006.

[12] N. M. Salleh, T. M. Iskandar, and M. M. Rahmat, "Earnings management and board characteristics: Evidence from Malaysia," Journal Pengurusan, vol. 24, pp. 77-103, 2005.

[13] S. N. Abdullah, "Board composition, audit committee and timeline of corporate financial reports in Malaysia," Journal of Corporate Ownership and Control, vol. 4, no. 2, pp. 33-45, 2006.

[14] Z. Z. Abidin, N. M. Kamal, and K. Jusoff, "Board structure and corporate performance in Malaysia," International Journal of Economics and Finance, vol. 1, no. 1, pp. 150-164, 2009.

[15] J. Conger and E. E. Lawler. (2009). Sharing leadership on corporate boards: A critical requirement for teamwork at the top. SSRN E-Library. [Online]. Available: http://ssrn.com/paper.

[16] R. B. Adam and D. Ferreira, "Women in the boardroom and their impact on governance and performance," Journal of Financial Economics, vol. 94, no. 2, pp. 291-309, 2009.

[17] B. Francis, I. Hasan, and Q. Wu, "Professors in the boardroom and their impact on corporate governance and firm performance," SSRN Working Paper, 2012.

[18] C. G. Ntim and K. A. Osei, "The impact of Corporate board meetings on corporate performance in South Africa," African Review of Economics and Finance, vol. 2, no. 2, pp. 83-103, 2011.

[19] N. Vafeas, "Board meeting frequency and firm performance," Journal of Financial Economics, vol. 53, pp. 113-142, 1999.

[20] J. Evans, R. Evans, and S. Loh, "Corporate governance and declining firm performance," International Journal of Business Studies, vol. 10 , no.1, pp. 1-18, 2002

[21] S. K. Johl, "Corporate entrepreneurship and corporate governance: An empirical analysis," Ph.D. dissertation, Dept. Business, University of Nottingham, UK, 2006.

[22] J. A. Conger, D. Finegold, and E. E. Lawler, "Appraising boardroom performance," Harvard Business Review, vol. 76, no. 1, pp. 136-148, 1998.

[23] D. Yermack, "Higher market valuation of companies with a small board of directors," Journal of Financial Economics, vol. 40, no. 2, 1 , pp. 85-211, 1996.

[24] D. R. Dalton and C. M. Daily. (2000). Board and Financial Performance, the Bigger is Better (Non Empirical Study). [Online]. Available: http://www.thecorporatelibrary.com/study

[25] P. D. Andres and E. Vallelado, "Corporate governance in banking: The role of the board directors," Journal of Banking and Finance, vol. 32, no. 12 , pp. $2570-2580,2008$.

[26] S. N. Shukeri, O. Shin, and M. S. Shaari, "Does board directors characteristics affect firm performance? Evidence from Malaysian public listed companies," International Business Research, vol. 5, no. 9 , pp. 120-127, 2012.

[27] A. B. Guner, U. Malmendier, and G. Tate, "Financial expertise of directors," Journal of Financial Economics, vol. 88, pp. 323-354, 2008.

[28] W. F. Wan Yusoff and A. Armstrong, "What competencies should directors possess? Malaysia perspective," International Journal of Business and Management, vol. 7, no. 2, pp. 142-149, 2012.
[29] D. C. Hambrick and P. A. Manson, "Upper echelons: The organization as a reflection of its top managers," Academy of Management Review, vol. 9, no. 2, pp. 193-206, 1984.

[30] D. P. Forbes and F. J. Milliken, "Cognition and corporate governance understanding boards of directors strategic decision group," Academic Management Review, vol. 24, no. 3, pp. 489-505, 1999.

[31] A. Carmeli, "The relative importance of the top management team's managerial skill," International Journal of Manpower, vol. 27, no. 1, pp. 9-36, 2006

[32] J. A. Conger and D. A. Ready, "Rethinking leadership competencies," Leader to Leader, 2004, vol. 32, pp. 41-47.

[33] Y. Y. Kor and C. Sundararamurthy, Experience-based human capital and social capital of outside directors. Journal of Management, vol. 35 , no. 44, pp. 981-1006, 2009.

[34] R. H. Myers, Classical and Modern Regression Application, 2nd Edition, Duxbury Press, CA, 1990.

[35] S. Bhagat and B. Bolton, "Corporate Governance and Firm Performance.” Journal of Corporate Finance, 14, pp. 257-273, 2008.

[36] M. Lipton and J. Lorsch, "A modest proposal for improved corporate governance," Business Lawyer, vol. 48, pp. 59-77, 1992.

[37] C. B. Ingley and N. T. van der Walt, "Board composition: Building better boards," Corporate Governance, vol. 3, no. 4, pp. 5-17, 2003.

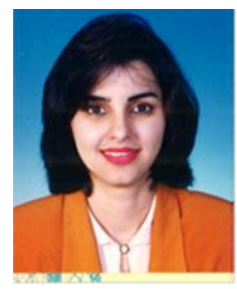

Satirenjit Kaur Johl is currently attached with University Teknologi Petronas (UTP) as a senior lecturer who holds a Bachelor degree in Public Administration (Hon) and an MSc in Management with a major in Human Resource Management from Universiti Utara Malaysia. Dr. Johl obtained her Doctor in Philosophy (Business) from The University of Nottingham, U.K. Furthermore, being actively involved in training and development she received the Certificate in Training and Development from Institute of Personnel and Development U.K in 1995. Prior to joining University Teknologi Petronas she was a lecturer with Universiti Utara Malaysia. She was a Programme Executive with Malaysian Professional Center and served IBM as a Management Support Executive. She has presented papers in international and local conferences and published journal papers and books in the area of Corporate Governance, Corporate Entrepreneurship and Small Business. She is member of the Institute of Internal Auditors Malaysia

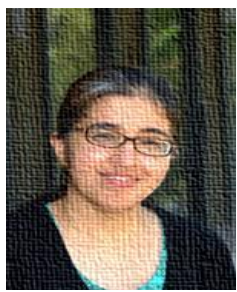

Shireenjit Johl is a senior lecturer in the School of Accounting, Economics and Finance at Deakin University. She has a Bachelor of Accounting (UUM), Master of Economics in Accounting (UNE) and $\mathrm{Ph} . \mathrm{D}$. (University of Melbourne) degree and is a Certified Practising Accountant, Australia (CPA). Dr Johl's academic experience has included being a lecturer at RMIT University and Multimedia University. She has a widespread research experience in the areas of audit and non-audit services markets, audit quality, earnings management, corporate governance, voluntary disclosure and accounting education. She has presented in local and international conferences and published in various refereed academic journal.

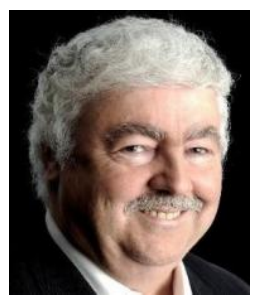

Barry J. Cooper is head of the School of Accounting, Economics and Finance at Deakin University. He has a Bachelor of Commerce, Master of Education and Ph.D. degree and is a Fellow of the Association of Chartered Certified Accountants (ACCA). He is a member of the Council of the ACCA (the largest global accounting professiona body in the world) and President for 2012-2013.Professor Cooper's senior management experience has included being Head of the Accounting Schools at the Hong Kong Polytechnic (1987 - 1991) and RMIT University (1993 - 1997). He was also National Director - Member Services of CPA Australia (19982000), when he was responsible for its member services and professional development operations throughout Australia and Asia. He returned to RMIT University in December 2000 until moving to Deakin University in 2007 , where, in addition to his role as Head of the School of Accounting, Economics and Finance, he teaches and researches in the areas of auditing, professional ethics, corporate governance and accounting education. In his spare time, Professor Cooper follows his passion as an organic olive oil grower and processor. 